\title{
Feeling It
}

EDITORIAL COMMENT

The eighth issue of Conversations is open-themed. Nonetheless, the articles gathered here coalesce around issues of feeling it. This is perhaps not altogether anomalous as all good writing is in some capacity a matter of feeling. But beginning with Andrew Norris, we are invited to consider how Cavell's moods inflect not simply his writing, but from there, his world and possibly the world. Managing to maintain attachments to professional philosophy after explicitly describing the world in a mooded way is perhaps amongst Cavell's notable (even Heideggarian) achievements. Next, Brad Tabas reminds us that our place in the universe costs money, is expensive-and that philosophy requires coming to terms with a mood of cannibalism that accompanies the stark realization and possibility that my voice or mood negates another's. Philosophy or thinking or what have you quite possibly eats itself. Michael McCreary notes a similar mood of failed catharsis in Dostoevsky's Underground Man and by so doing, provides a sorely needed Cavellian commentary on the possibility of failed expression, of what happens when the costs of mooding the world results not in ordinary transcendence, but extraordinary rage. Charles Djordjevic looks to what one might perhaps term a Cavellian sense of "play" to deal with extraordinary railings. The move to take language on holiday, that is, is not indicative necessarily of Wittgensteinian error but perhaps a type of philosophical therapy afforded to human beings by virtue of (a Kierkegaardian) faith. Lucas Thompson more subtly exposes the lack of faith in contemporary treatment of Cavell's philosophical work on film, exposing the naïve belief that takes Cavell to be naïve for not engaging forcefully enough in "ideology critique"; not only does Thompson champion Cavell's genre of remarriage comedies in rebuttal, but he ably adds another film to the mix. Lastly, a welcome and spirited addendum concludes the issue in dialogic exchange. Two recently published Cavellian authors, Rex Butler and Catherine Wheatley, discuss how Cavell might be bet- 
ter integrated into a wider, more contentious, and certainly more mooded, world of gender and identity politics.

With all best wishes, SÉRGIO AND AMIR 